\title{
Identification of Crucifer Accessions from the NC-7 and NE-9 Plant Introduction Collections That Are Resistant to Black Rot (Xanthomonas
} campestris pv. campestris) Races 1 and 4

\author{
Phillip D. Griffiths ${ }^{1}$
}

Department of Horticultural Sciences, Cornell University NYSAES, 314 Hedrick Hall, Geneva, NY 14456

Laura Fredrick Marek

North Central Regional Plant Introduction Station, Iowa State University, Ames, IA 50011

\section{Larry D. Robertson}

North East Regional Plant Introduction Station, USDA, NYSAES, Geneva, NY 14456

Additional index words. Brassica oleracea, Brassica rapa, Brassica juncea, Brassica carinata, Brassica nigra, disease resistance

Abstract. Black rot, caused by Xanthomonas campestris pv. campestris (Pam.) Dawson (Xcc), is a serious disease of vegetable crucifers worldwide. The USDA NC-7 and NE-9 regional PI stations maintain vegetable, mustard, and oilseed crucifers, of which 4084 accessions were available for testing, representing 23 genera and 125 species. These accessions were evaluated for resistance to black rot after wound inoculation with race 1 of the pathogen. Accessions that were symptomless for race 1 of Xcc were replanted and inoculated with race 4 of the pathogen to identify accessions with resistance to both races. Symptomless responses were observed in 362 accessions of the mustard species (Brassica juncea, Brassica carinata, and Brassica nigra), in particular, B. juncea for which 353 of the $\mathbf{3 8 9}$ accessions tested were symptomless. Resistance was identified in five accessions of B. carinata out of 63 evaluated (PI 193460, PI 193959, PI 194254, PI 280230, PI 633077) determined by repeated symptomless responses after inoculation and four accessions of B. nigra from the 83 evaluated (PI 197401, A 25399, A 25401, PI 458981). Five accessions of Brassica rapa (PI 633154, A9285, PI 340208, PI 597831, PI 173847) were identified, which represent promising new sources of resistance to Xcc. Incomplete resistance was identified in an accession of Eruca sativa (PI 633207), an accession of Lepidium spp. (PI 633265), an accession of Sinapis arvensis (PI 296079), and two accessions of B. napus (PI 469733 and PI 469828). These identified accessions represent germplasm that can be used in breeding for resistance to Xcc in vegetable crucifers through interspecific crossing.

Black rot is a bacterial disease of crucifer species caused by Xanthomonas campestris pv. campestris (Xcc). Xcc is prevalent worldwide and is a destructive disease of Brassica oleracea vegetables such as cabbage, broccoli, and cauliflower (Williams, 1980). Xcc is seed-borne and also can overwinter on cruciferous weeds and wild relatives of cultivated Brassica crops (Cook et al., 1952; Schaad and Dianese, 1981). Symptoms of the disease include blackening of the veins in petioles and characteristic V-shaped lesions originating from the leaf margin, which enlarge causing the plant to wilt and eventually rot. Currently, the most effective

Received for publication 25 Oct. 2008. Accepted for publication 21 Dec. 2008.

${ }^{1}$ To whom reprint requests should be addressed; e-mailpdg8@cornell.edu.
436606 from China, also determined to be controlled by multiple genes (Dickson and Hunter, 1987; Hunter et al., 1987). These sources have been used in the development of black rot-resistant breeding lines, including Badger \#16 (Williams, University of Wisconsin); NY4002 (Dickson, Cornell University); and Cornell 101, Cornell 102, and Cornell 103 (Griffiths, Cornell University). However, the resistance is typically incomplete and difficult to incorporate into hybrid cultivars (Camargo et al., 1995). Resistance has been reported in the mustard species $B$. nigra, B. juncea, and B. carinata (Guo et al., 1991; Taylor et al., 2002; Tonguc and Griffiths, 2004a; Westman et al., 1999), including B. juncea accessions PI 633077 and PI 633078 (previously A 19182 and A 19183), and B. carinata accessions PI 199947 and PI 199949 (Guo et al., 1991) and used in the creation of interspecific hybrids (Tonguc et al., 2003; Tonguc and Griffiths, 2004b).

Xcc has been characterized into at least six distinct races, the most important of these being races 1 and 4, which account for over $90 \%$ of black rot disease worldwide (Vicente et al., 2001). B. oleracea accessions have not been identified that exhibit complete resistance to races 1 and 4 , but breeding lines have been developed that exhibit incomplete resistance to these races. Related crucifer species, including $B$. carinata and $B$. juncea, exhibit resistance to Xcc races 1 and 4 , that appear to be controlled by a single gene (Guo et al., 1991; Hansen and Earle, 1995; Taylor et al., 2002; Tonguc et al., 2003; Tonguc and Griffiths, 2004b; Vicente et al., 2002).

To effectively use germplasm resources for interspecific hybridization with $B$. oleracea, it will be important to determine the presence and frequency of Xcc resistance not just within cultivated Brassica vegetables, but also within related crucifer accessions. Resistance may then be exploited through interspecific crosses of $B$. oleracea with related species. Crucifer accessions could provide important resistance sources for the development of hybrid Brassica vegetables by contributing new resistance genes for Xcc or genes that can be incorporated into cole crops more effectively. The aim of this research was to evaluate crucifer species at the juvenile stage to quantify the presence, frequency, and potential use of accessions for introgression of Xcc resistance. To achieve this, the crucifer accessions from the NC-7 (Ames, IA) and NE-9 (Geneva, NY) USDA regional PI centers were inoculated and evaluated for resistance to race 1 and race 4 of Xcc using the wound inoculation technique (Griffiths and Roe, 2005).

\section{Materials and Methods}

Plant material. The USDA crucifer species are maintained at the NC-7 and NE-9 regional PI centers with vegetable crucifers being maintained primarily at the NE-9 collection and oilseed and mustard accessions being maintained in the $\mathrm{NC}-7$ collection. The 
crucifer collections held at NE-9 and NC-7 comprise 2857 and 3129 , respectively $(\approx 70 \%$ of which belong to Brassica spp. with the remainder representing related crucifer species). These 5985 accessions comprise a total of 125 crucifer species representing 23 genera of which 4084 were available for evaluation of resistance to Xcc (Table 1). Eight seeds of each of the 4084 accessions were sown in greenhouses at Geneva, NY, in 32-cell (125 $\mathrm{cm}^{3}$ ) Styrofoam trays in 'Cornell Mix' (Boodley and Sheldrake, 1982) with one seed per cell (Speedling, Sun City, FL) with multiple planting dates between June 2005 and June 2006. Cabbage cultivars were planted as susceptible controls.

Inoculation. The accessions were grown to the two to three true-leaf stage at $\approx 3$ to 4 weeks dependent on the species being tested. Seeds were sown in a greenhouse at $23 / 20{ }^{\circ} \mathrm{C}$ day/night with a 14-h photoperiod under $1000-\mathrm{W}$ metal halide lamps $\left(300 \mu \mathrm{mol} \cdot \mathrm{m}^{-2} \cdot \mathrm{s}^{-1}\right)$ in preparation for the inoculation. Temperatures were raised to $26 / 23{ }^{\circ} \mathrm{C}$ after inoculation to enhance disease responses. Isolates of Xcc determined to be race 1 and race 4 based on the differential cultivar screening (Vicente et al., 2001) were recovered from infected cabbages in New York (Helene Dillard, Cornell University), which were used to determine resistance of the crucifer accessions to Xcc. These Xcc isolates were grown on YDCP medium (Shelton and Hunter, 1985) for 3 to $4 \mathrm{~d}$ and used to needleinoculate the accessions and control plants. The wound inoculation (Shaw and Kado, 1988) involved piercing two of the true leaves either side of the midrib with needles dipped in the Xcc isolates (Griffiths and Roe, 2005) for at least two leaves per plant. The inoculation was undertaken at the two to three true-leaf stage. Plants were evaluated 10 to $14 \mathrm{~d}$ after the inoculation using a rating scale of 1 to $5(1=$ completely resistant, $5=$ completely susceptible), whereby 1 = symptomless, $2=$ minimal symptoms from the point of wounding, 3 = symptoms beyond point of wounding, $4=$ some systemic movement beyond the infected leaf, and $5=$ highly susceptible systemic response resulting in plant death (Tonguc et al., 2003). The initial inoculation involved testing eight plants each of 4084 accessions with a race 1 isolate of Xcc. The 561 accessions that were symptomless after the Xcc race 1 inoculation were replanted and evaluated with the race 4 isolate to identify accessions that exhibited resistance to both races 1 and 4 .

\section{Results}

All control plants exhibited black rot symptoms when wound-inoculated. Of the 4084 accessions, 561 were identified for a retest determined by evaluation of at least six plants with zero or very minimal infection from the point of infection after inoculation with race $1 \mathrm{Xcc}$ inoculation. The vast majority of the 561 accessions exhibiting symptomless responses after inoculation with race 1 Xcc belonged to the mustard species $B$.
Table 1. Crucifer species available from the NC-7 and NE-9 regional PI centers that were evaluated for Xanthomonas campestris pv. campestris (Pam.) Dawson resistance (total 4084). \begin{tabular}{ll}
\hline Species & Number of accessions \\
\hline Alysumalysoides
\end{tabular} Alyssum alyssoides

Alyssum bracteatum

Alyssum dasycarpum var. dasycarpum

Alyssum dasycarpum var. minus

Alyssum desertorum

Alyssum flahaultianum

Alyssum granatense

Alyssum lenense

Alyssum linifolium

Alyssum minutum

Alyssum montanum

Alyssum nebrodense

Alyssum scutigerum

Alyssum simplex

Alyssum stapfii

Alyssum strigosum

Alyssum tortuosum

Alyssum wulfenianum

Aurinia corymbosa

Barbarea intermedia

Barbarea verna

Berteroa incana

Biscutella didyma subsp. didyma

Biscutella didyma subsp. lyrata

Brassica barrelieri

Brassica carinata

Brassica deflexa

Brassica deflexa subsp. leptocarpa

Brassica fruticulosa

Brassica fruticulosa subsp. fruticulosa

Brassica fruticulosa subsp. glaberrima

Brassica fruticulosa subsp. mauritanica

Brassica fruticulosa subsp. pomeliana

Brassica fruticulosa subsp. radicata

Brassica gravinae var. brachyloma

Brassica gravinae var. djurdjurae

Brassica juncea

Brassica juncea var. longidens

Brassica maurorum

Brassica napus

Brassica napus var. napus

Brassica nigra

Brassica oleracea

Brassica oleracea var. acephala

Brassica oleracea var. aff acephala

Brassica oleracea var. alboglabra

Brassica oleracea var. botrytis

Brassica oleracea var. capitata

Brassica oleracea var. costata

Brassica oleracea var. gemmifera

Brassica oleracea var. gongylodes

Brassica oleracea var. italica

Brassica oleracea var. medullosa

Brassica oleracea var. oleracea

Brassica oleracea var. palmifolia

Brassica oleracea var. ramosa

Brassica oleracea var. sabauda

Brassica oleracea var. sabellica

Brassica oleracea var. selenesia

Brassica rapa

Brassica rapa subsp. campestris

Brassica rapa subsp. chinensis

Brassica rapa subsp. dichotoma

Brassica rapa subsp. japonica

Brassica rapa subsp. narinosa

Brassica rapa subsp. nipposinica

Brassica rapa subsp. oleifera

Brassica rapa subsp. rapa

Brassica rapa subsp. rapifera

Brassica rapa subsp. trilocularis

Brassica rapa var. parachinensis

Brassica rapa var. pekinensis

Brassica rapa var. silvestris 
Table 1. (Continued) Crucifer species available from the NC-7 and NE-9 regional PI centers that were evaluated for Xanthomonas campestris pv. campestris (Pam.) Dawson resistance (total 4084).

\begin{tabular}{|c|c|}
\hline Species & Number of accessions \\
\hline Brassica rapa var. utilis & 3 \\
\hline Brassica repanda subsp. almeriensis & 1 \\
\hline Brassica souliei subsp. amplexicaulis & 1 \\
\hline Brassica sp. & 3 \\
\hline Brassica tournefortii & 20 \\
\hline Camelina alyssum & 1 \\
\hline Camelina hispida var. grandiflora & 1 \\
\hline Camelina laxa & 1 \\
\hline Camelina microcarpa & 8 \\
\hline Camelina rumelica subsp. transcaspica & 1 \\
\hline Camelina sativa & 36 \\
\hline Crambe abyssinica & 83 \\
\hline Crambe filiformis & 10 \\
\hline Crambe hispanica & 2 \\
\hline Crambe hispanica subsp. glabrata & 17 \\
\hline Crambe hispanica subsp. hispanica & 35 \\
\hline Crambe juncea & 2 \\
\hline Crambe kralikii & 1 \\
\hline Crambe maritima & 1 \\
\hline Crambe pritzelii & 1 \\
\hline Crambe sp. & 2 \\
\hline Crambe tataria & 1 \\
\hline Diplotaxis erucoides subsp. Erucoides & 1 \\
\hline Diplotaxis muralis & 1 \\
\hline Diplotaxis tenuifolia & 2 \\
\hline Enarthrocarpus arcuatus & 1 \\
\hline Eruca pinnatifida & 2 \\
\hline Eruca sativa & 172 \\
\hline Eruca sativa subsp. longirostris & 1 \\
\hline Eruca vesicaria & 4 \\
\hline Erucastrum brevirostre & 1 \\
\hline Erucastrum elatum & 1 \\
\hline Erucastrum elatum var. microspermum & 1 \\
\hline Erucastrum elatum var. scabriusculum & 1 \\
\hline Erucastrum leucanthum & 3 \\
\hline Erucastrum nasturtiifolium & 1 \\
\hline Erucastrum nasturtiifolium subsp. sudrei & 1 \\
\hline Erucastrum rifanum & 1 \\
\hline Erucastrum varium & 1 \\
\hline Erucastrum varium subsp. varium & 1 \\
\hline Erucastrum virgatum & 1 \\
\hline Erucastrum virgatum subsp. baeticum & 1 \\
\hline Erucastrum virgatum subsp. pseudosinapis & 1 \\
\hline Erucastrum virgatum subsp. virgatum & 1 \\
\hline Erysimum asperum & 1 \\
\hline Erysimum aucherianum & 1 \\
\hline Erysimum baeticum & 1 \\
\hline Erysimum cheiranthoides & 3 \\
\hline Erysimum crassipes & 1 \\
\hline Erysimum creticum & 1 \\
\hline Erysimum cuspidatum & 2 \\
\hline Erysimum diffusum & 2 \\
\hline Erysimum duriaei subsp. pyrenaicum & 1 \\
\hline Erysimum favargeri & 1 \\
\hline Erysimum graecum & 1 \\
\hline Erysimum gramineum & 1 \\
\hline Erysimum incanum & 1 \\
\hline Erysimum inconspicuum var. coarctatum & 1 \\
\hline Erysimum linifolium & 1 \\
\hline Erysimum nevadense subsp. collisparsum & 1 \\
\hline Erysimum nevadense subsp. rondae & 1 \\
\hline Erysimum odoratum & 1 \\
\hline Erysimum olympicum & 1 \\
\hline Erysimum penyalarense & 1 \\
\hline Erysimum raulinii & 1 \\
\hline Erysimum repandum & 3 \\
\hline Erysimum scabrum & 1 \\
\hline Erysimum sisymbrioides & 1 \\
\hline Erysimum smyrnaeum & 1 \\
\hline Erysimum virgatum & 3 \\
\hline Erysimum witmannii & 1 \\
\hline Hesperis kotschyana & 1 \\
\hline Hesperis matronalis & 4 \\
\hline
\end{tabular}

(Continued on next page) carinata, B. nigra, and $B$. juncea, in particular B. juncea, accessions, from which 323 were determined to have a mean rating of 1 when inoculated with Xcc. Additionally, five B. carinata (PI 193460, PI 193959, PI 194254, PI 280230, PI 633077) and four $B$. nigra (PI 197401, A25399, A25401, PI 458981) accessions were determined to be resistant based on symptomless responses to the inoculation. The list of mustard accessions determined to be resistant is available through the GRIN web site for the NC-7 regional PI station. Because the majority of resistant accessions within $B$. juncea were determined to be resistant to Xcc, a third test focused on crucifer accessions not belonging to mustard species. This involved retesting 134 accessions belonging to 17 crucifer species, the individual accessions of which are listed in Table 2.

The most promising 10 accessions were selected from this screen and focused on nonmustard species so as to represent new sources of resistance for breeding purposes (Table 3 ). Minimal symptom responses were observed in an accession of Eruca sativa (PI 633207), an accession of Lepidium spp. (PI 633265), an accession of Sinapis arvensis (PI 296079), and two accessions of B. napus (PI 469733 and PI 469828). Based on this more extensive screen, five accessions were identified representing newly identified Xcc-resistant sources in a species more easily crossed to $B$. oleracea (all belonged to $B$. rapa or subspecies of $B$. rapa). The five accessions A 9285, PI 173847 , PI 340208, PI 597831, and PI 633154 were evaluated in a final test of five plants with Xcc races 1 and 4 and were scored with ratings of 1 or 2 in all plants tested (Table 4) and represent newly identified Xcc sources that can be used for breeding black rot-resistant Brassica vegetables after interspecific crosses with $B$. oleracea.

\section{Discussion}

Host plant resistance is an important approach to controlling Xcc, particularly in the economically important Brassica vegetable species such as cabbage, cauliflower, and broccoli. No B. oleracea cultivars with complete resistance to the most common Xcc races 1 and 4 have been developed. However, cabbage breeding lines, including Badger \#16 (P.H. Williams, Univ. of Wisconsin); Cornell 101, 102, and 103; and some commercial cultivars, have been documented as incompletely resistant Xcc (Griffiths and Roe, 2005). Incomplete resistance to Xcc in $B$. oleracea species continues to be problematic worldwide despite the use of remote seed increase facilities and hot water treatment of seeds, highlighting the need to use more effective resistance genes from outside the species through interspecific crossing (Hansen and Earle, 1995; Tonguc et al., 2003;Tonguc and Griffiths, 2004b).

Previous work with interspecific sources of resistance has been undertaken, including the transfer of resistance from $B$. carinata 
Table 1. (Continued) Crucifer species available from the NC-7 and NE-9 regional PI centers that were evaluated for Xanthomonas campestris pv. campestris (Pam.) Dawson resistance (total 4084).

\begin{tabular}{|c|c|}
\hline Species & Number of accessions \\
\hline Hesperis sibirica & 1 \\
\hline Hirschfeldia incana & 1 \\
\hline Hirschfeldia incana subsp. consobrina & 1 \\
\hline Hirschfeldia incana subsp. Geniculata & 1 \\
\hline Iberis amara & 2 \\
\hline Isatis glauca & 1 \\
\hline Isatis tinctoria & 1 \\
\hline Lepidium alluaudii & 1 \\
\hline Lepidium apetalum & 1 \\
\hline Lepidium bonariense & 1 \\
\hline Lepidium campestre & 8 \\
\hline Lepidium densiflorum & 2 \\
\hline Lepidium graminifolium & 1 \\
\hline Lepidium heterophyllum & 1 \\
\hline Lepidium hirtum subsp. atlanticum & 1 \\
\hline Lepidium hirtum subsp. calycotrichum & 1 \\
\hline Lepidium hirtum subsp. dhavense & 1 \\
\hline Lepidium hirtum subsp. nebrodense & 1 \\
\hline Lepidium meyenii & 1 \\
\hline Lepidium perfoliatum & 2 \\
\hline Lepidium ruderale & 3 \\
\hline Lepidium sativum & 77 \\
\hline Lepidium $\mathrm{sp}$. & 3 \\
\hline Lepidium spinosum & 2 \\
\hline Lepidium virginicum & 1 \\
\hline Lepidium virginicum var. pubescens & 1 \\
\hline Matthiola incana & 1 \\
\hline Matthiola longipetala & 1 \\
\hline Raphanus sativa & 626 \\
\hline Sinapis alba & 116 \\
\hline Sinapis alba subsp. alba & 1 \\
\hline Sinapis alba subsp. mairei & 2 \\
\hline Sinapis arvensis & 35 \\
\hline Sinapis arvensis subsp. arvensis & 18 \\
\hline Sinapis flexuosa & 1 \\
\hline Thlaspi alpestre & 1 \\
\hline Thlaspi arvense & 5 \\
\hline Thlaspi nevadense & 1 \\
\hline Thlaspi perfoliatum subsp. tineoi & 1 \\
\hline X Brassicoraphanus sp. & 1 \\
\hline Total & 4,084 \\
\hline
\end{tabular}

Table 2. Species and specific accessions re-evaluated for resistance to Xanthomonas campestris pv. campestris (Pam.) Dawson races 1 and 4.

\begin{tabular}{|c|c|c|c|c|c|}
\hline Species & Accession & Species & Accession & Species & Accession \\
\hline \multirow[t]{9}{*}{$\begin{array}{l}\text { Brassica } \\
\text { carinata }\end{array}$} & PI193460 & $\begin{array}{l}\text { Brassica napus, } \\
\text { concl. }\end{array}$ & PI469878 & $\begin{array}{l}\text { Brassica rapa, } \\
\text { concl. }\end{array}$ & PI340199 \\
\hline & PI193959z & & PI469889 & & PI384534 \\
\hline & PI194254 & & PI469906 & & PI391548z \\
\hline & PI197403 & & PI469911 & & PI419212 \\
\hline & PI231046 & & PI469912 & & PI426177 \\
\hline & PI280230 & & PI469916 & & PI426258 \\
\hline & PI633077 & & PI469924 & & PI426266 \\
\hline & PI633078 & & PI469955 z & & PI426268 \\
\hline & PI633080 & & PI469959z & & PI426271 \\
\hline $\begin{array}{l}\text { Brassica } \\
\quad \text { fruticulosa }\end{array}$ & Ames 21302 & & PI469974 & & PI426277 \\
\hline \multirow{12}{*}{$\begin{array}{l}\text { Brassica } \\
\text { napus }\end{array}$} & Ames $6096^{z}$ & & PI470080 & & PI426286 \\
\hline & Ames 26633 & Brassica nigra & PI633140 & & PI537016 \\
\hline & Ames $26635^{z}$ & & PI131512 & & PI633154 \\
\hline & PI251614 & & PI169067 & & PI633158 \\
\hline & PI458919 & & PI173860 & & PI633161 \\
\hline & PI458949 & & PI183920 & & Ames 9285 \\
\hline & PI458956 ${ }^{z}$ & & PI197401 & & PI340208 \\
\hline & PI458967 & & PI426410 & & PI597831 \\
\hline & PI458979 & & PI633143 & & PI173847 \\
\hline & PI458980 & & PI633145 & & PI390962z \\
\hline & PI469732 & & Ames 25399 & & PI390963z \\
\hline & PI469733 & & Ames $25401^{z}$ & & PI390964z \\
\hline
\end{tabular}

(Continued on next page) accession PI199947 to B. oleracea (Hansen and Earle, 1995) through protoplast fusion, which has proved difficult to stabilize in a $B$. oleracea plant type (Tonguc et al., 2003). Complications arising from interspecific crosses with $B$. oleracea through sexual crosses include different chromosome numbers in the parents. These barriers can be overcome with techniques including embryo rescue and protoplast fusion, but complications such as aneuploidy in breeding lines can also occur. Successful introgression of black rot resistance using the mustard species $B$. juncea has also been evaluated (Tonguc and Griffiths, 2004b) using accessions A 19182 and A 19183 identified from the NC-7 B. carinata collection, which were determined to be incorrectly identified. These accessions have since been recategorized as $B$. juncea accessions PI 633077 and PI 633078, respectively. The accessions were morphologically very distinct from other $B$. carinata accessions evaluated (Tonguc and Griffiths, 2004a) and subsequently reidentified by Gomez-Campo as B. juncea. The accessions are of an uncertain Canadian source that was acquired by the NC-7 collection.

Black rot resistance can be expressed at the juvenile, mature, or both juvenile and mature plant stages (Hunter et al., 1987). Differential responses in disease reactions of accessions and species in this study were observed that were likely influenced by plant type and growth rate. The vigorous growth of the oilseed and mustard species and the rapid transition to flowering compromised accurate rating of Xcc symptoms based on the 1 to 5 scale typically used. Rating was modified based on the plant species type to make a determination of resistance to Xcc.

Accessions previously used in interspecific transfer of resistance to Xcc (Hansen and Earle, 1995; Tonguc and Griffiths, 2004a) have belonged to the species $B$. carinata and $B$. juncea, which are B-genome crucifers according to the relationships of Brassica species determined by U (1935). The barriers to successful transfer from Bgenome Brassica species are challenging and likely more difficult than transfer from Agenome and $\mathrm{C}$-genome types as a result of genetic distance (Cunha et al., 2004). The identification of the $B$. rapa accessions PI 633154, A9285, PI 340208, PI 597831, and PI 173847 could prove important in enabling transfer of resistance to Xcc from a different species with potentially fewer crossing barriers. Of the five $B$. rapa accessions identified with resistance to Xcc, all have the oilseed plant growth type, and four of the accessions have been identified as subspecies of $B$. rapa. It is possible that one or more of these accessions has been misidentified in the B. rapa species, because the vast majority of resistant accessions belong to the related $B$. juncea species. Interspecific crossing to generate hybrids after natural crosspollinations is currently being undertaken to determine whether techniques such as protoplast fusion or embryo rescue would also be required for these newly identified sources to transfer Xcc resistance. 
Table 2. (Continued) Species and specific accessions re-evaluated for resistance to Xanthomonas campestris pv. campestris (Pam.) Dawson races 1 and 4

\begin{tabular}{|c|c|c|c|c|c|}
\hline Species & Accession & Species & Accession & Species & Accession \\
\hline & PI469734 & $\begin{array}{l}\text { Brassica } \\
\quad \text { oleracea }\end{array}$ & PI458981 & & Ames $19215^{z}$ \\
\hline & PI469750z & & $\mathrm{G} 30727^{\mathrm{z}}$ & & $\mathrm{G} 30804^{\mathrm{z}}$ \\
\hline & PI469752 & & $\mathrm{G} 30734^{\mathrm{z}}$ & & PI597833 \\
\hline & PI469761 ${ }^{z}$ & & PI600985 & Camelina sativa & NSL74254 z \\
\hline & PI469807 & Brassica rapa & PI358284 & Crambe abbyssinica & NSL74278z \\
\hline & PI469808 & & Ames 21738 & & PI633205 \\
\hline & PI469809 & & PI163497 & Eruca sativa & PI633207 \\
\hline & PI469818 & & PI169070 & & PI633226 \\
\hline & PI469819 & & PI174803 & Erysimum diffusum & PI586611 \\
\hline & PI469828 & & PI175063 & Hesperis matronalis & PI633241 \\
\hline & PI469829 & & PI179643 & & PI597856 \\
\hline & PI469837 z & & $\mathrm{PI} 204683^{z}$ & $\begin{array}{l}\text { Lepidium } \\
\quad \text { heterophyllum }\end{array}$ & PI175762z \\
\hline & PI469845 & & PI217932 & Lepidium sativum & PI253154 \\
\hline & PI469846 & & PI217936 ${ }^{z}$ & & PI633265 \\
\hline & PI469847 z & & PI226505 & Lepidium & PI305277 \\
\hline & PI469850 & & PI250138 & Sinapis alba & PI633308 \\
\hline & PI469851 & & PI254360 & & PI633316 \\
\hline & PI469856 & & PI269431 ${ }^{z}$ & & PI633348 \\
\hline & PI469860 & & PI269446 & & PI597862 \\
\hline & PI469862 & & PI303135 & & PI633370 \\
\hline & PI469865 & & PI312124 & Sinapis arvensis & PI633371 \\
\hline & PI469872z & & PI340184 & & \\
\hline
\end{tabular}

${ }^{\mathrm{z}}$ Susceptible.

Table 3. Accessions selected for final evaluation with Xanthomonas campestris pv. campestris (Pam.) Dawson races 1 and 4.

\begin{tabular}{|c|c|c|}
\hline Species & Accession & Rating \\
\hline Brassica napus & PI 469733 & $1-2$, minimal response \\
\hline Brassica napus & PI 469828 & $1-2$, minimal response \\
\hline Brassica rapa & PI 633154 & 1, symptomless \\
\hline Brassica rapa subsp. dichotoma & Ames 9285 & 1 , symptomless \\
\hline Brassica rapa subsp. dichotoma & PI 340208 & 1, symptomless \\
\hline Brassica rapa subsp. oleifera & PI 597831 & 1, symptomless \\
\hline Brassica rapa subsp. trilocularis & PI 173847 & 1 , symptomless \\
\hline Eruca sativa & PI 633207 & $1-2$, minimal response \\
\hline Lepidium sp. & PI 633265 & $1-2$, minimal response \\
\hline Sinapis arvensis subsp. arvensis & PI 296079 & $1-2$, minimal response \\
\hline
\end{tabular}

Table 4. B. rapa accessions identified as resistant to Xanthomonas campestris pv. campestris (Pam.) Dawson $(\mathrm{Xcc})$ races 1 and 4 in final retest.

\begin{tabular}{lllr}
\hline Accession & \multicolumn{1}{c}{ Species } & Xcc race 1 & Xcc race4 \\
\hline Ames9285 & Brassica rapa subsp. dichotoma & $1-1-1-1-1$ & $1-1-1-1-1$ \\
PI 173847 & Brassica rapa subsp. trilocularis & $2-1-2-1-1$ & $1-1-1-1-1$ \\
PI 340208 & Brassica rapa subsp. dichotoma & $1-1-1-1-1$ & $1-1-1-1-1$ \\
PI 597831 & Brassica rapa subsp. oleifera & $1-1-1-1-1$ & $1-1-1-1-1$ \\
PI 633154 & Brassica rapa & $2-1-1-1-1$ & $1-1-1-1-1$ \\
\hline
\end{tabular}

The accessions identified in this study represent newly identified sources exhibiting resistance to the two major worldwide Xcc races 1 and 4 . These accessions can be used to transfer this resistance to Brassica vegetables through interspecific hybridization. They represent sources identified as $B$. rapa, which may have less barriers to the transfer of Xcc resistance than those encountered transferring resistance from $B$. juncea nad $B$. carinata accessions (Tonguc et al., 2003; Tonguc and Griffiths, 2004b). If interspecific hybrids with $B$. oleracea can be successfully generated, these accessions can be used to introgress Xcc resistance into Brassica vegetable species, reducing the worldwide limitations to production caused by this pathogen. using PCR-RFLP of chloroplast DNA. HortScience 39:481-484.

Dickson, M.D. and J.E. Hunter. 1987. Sources of resistance to black rot of cabbage expressed in seedlings and adult plants. Plant Dis. 71:263266.

Griffiths, P.D. and C. Roe. 2005. Response of Brassica oleracea var. capitata to wound and spray inoculation with Xanthomonas campestris pv. campestris in juvenile and mature plants. HortScience 40:47-49.

Guo, H., M.H. Dickson, and J.E. Hunter. 1991. Brassica napus sources of resistance to black rot in crucifers and inheritance of resistance. HortScience 26:1545-1547.

Hansen, L.N. and E.D. Earle. 1995. Transfer of resistance to Xanthomonas campestris pv. campestris into Brassica oleracea L. by protoplast fusion. Theor. Appl. Genet. 91:1293-1300.

Hunter, J.E., M.H. Dickson, and J.W. Ludwig. 1987. Sources of resistance to black rot of cabbage expressed in seedlings and adult plants. Plant Dis. 71:263-266.

Schaad, N.W. and J.C. Dianese. 1981. Cruciferous weeds as sources of inoculum of Xanthomonas campestris in black rot of crucifers. Phytopathology 71:1215-1220.

Shaw, J.J. and C.I. Kado. 1988. Whole plant wound inoculation for consistent reproduction of black rot of crucifers. Phytopathology 78:981-986.

Shelton, A.M. and J.E. Hunter. 1985. Evaluation of the potential of the flea bettle Phyllotreta cruciferae to transmit Xanthomonas campestris pv. campestris, casual agent of black rot of crucifers. Can. J. Plant Pathol. 7:308-310.

Taylor, J.D., J. Conway, S.J. Roberts, D. Astley, and J.G. Vicente. 2002. Sources and origin of resistance to Xanthomonas campestris pv. campestris in Brassica genomes. Phytopathology 92:105-111.

Tonguc, M., E. Earle, and P.D. Griffiths. 2003. Segregation distortion of Brassica carinata derived black rot resistance in Brassica oleracea. Euphytica 134:269-276.

Tonguc, M. and P.D. Griffiths. 2004a. Evaluation of Brassica carinata accessions for resistance to black rot (Xanthomonas campestris pv. campestris). HortScience 39:952-954.

Tonguc, M. and P.D. Griffiths. 2004b. Development of black rot resistant interspecific hybrids between $B$. oleracea $L$. cultivars and accession A 19182. Euphytica 136:313-318.

U, N. 1935. Genome analysis in Brassica with special reference to the experimental formation of Brassica napus and peculiar mode of fertilization. Japan J. Bot. 7:389-452.

Vicente, J.G., J. Conway, S.J. Roberts, and J.D. Taylor. 2001. Identification and origin of Xanthomonas campestris pv. campestris races and related pathovars. Phytopathology 91:492-499.

Bain, D.C. 1952. Reaction of brassica seedlings to black rot. Phytopathology 42:497-500.

Boodley, J.W. and R. Sheldrake, Jr. 1982. Cornell peat-lite mixes for commercial plant growing. New York Agr. Exp. Sta. Agr. Info. Bul. 43.

Camargo, L.E.A., P.H. Williams, and T.C. Osborn. 1995. Mapping of quantitative loci controlling resistance to Brassica oleracea to Xanthomonas campestris pv. campestris in the field and greenhouse. Phytopathology 85:12961300.

Cook, A.A., R.H. Larson, and J.C. Walker. 1952 Relation of the black rot pathogen to cabbage seed. Phytopathology 42:316-320.

Cunha, C., M. Tonguc, and P.D. Griffiths. 2004. Discrimination of diploid Brassica species
Vicente, J.G., J.D. Taylor, A.G. Sharpe, I.A.P. Parkin, D.J. Lydiate, and G.J. King. 2002. Inheritance of race-specific resistance to Xanthomonas campestris pv. campestris in Brassica genomes. Phytopathology 92:1134-1141.

Westman, A.L., S. Kresovich, and M.H. Dickson. 1999. Regional variation in Brassica nigra and other weedy crucifers for disease reaction to Alternaria brassicicola and Xanthomonas campestris pv. campestris. Euphytica 106:253259.

Williams, P.H. 1980. Black rot: A continuing threat to world crucifers. Plant Dis. 64:736742 .

Williams, P.H., T. Staub, and J.C. Sutton. 1972. Inheritance of resistance in cabbage to black rot. Phytopathology 62:247-252. 